Marek Oktaba

Towarzystwo Pomocy

im. św. Brata Alberta
Etyka pracy socjalnej w filozofii spotkania i dialogu, red. M. Duda, I. Rybka, H. Kaszyński, Kraków 2017, s. 117-132 (Praca Socjalna w Teorii i Działaniu, 4).

DOI: http://dx.doi.org/10.15633/9788374386425.09

\title{
Towarzyszenie duchowe - metoda pracy socjalnej stosowana przez br. Jerzego Marszałkowicza
}

\author{
Spiritual accompaniment - a method of social work \\ used by Br. Jerzy Marszałkowicz
}

\begin{abstract}
Abstrakt: Br. Jerzy Marszałkowicz (ur. 1931), kluczowa postać wśród założycieli Towarzystwa Pomocy im. św. Brata Alberta, który kilkadziesiąt lat poświęcił pracy wśród bezdomnych, w swoim praktycznym działaniu stosował metodę, która w niniejszym artykule jest nazwana "metodą towarzyszenia duchowego", a będąca jednym $z$ wariantów prowadzenia indywidualnego przypadku. Jest to taka metodą pracy socjalnej, gdzie przemawia się mniej słowami, a bardziej obecnością i własnym przykładem, z prowadzeniem walki duchowej mającej na celu uzyskanie wolności. Wśród nieodzownych warunków przy stosowaniu tej metody są: równość między obydwiema stronami pomocy, umiejętność wykorzystywania porażek i deficytów,

Abstract: Br. Jerzy Marszałkowicz (b. 1931), key figure among the founders of The Brother Albert Aid Society, who spent decades working among the homeless, in his practical action applied method, which in this article is called "Spiritual accompaniment method", and which is a variant of case work. It is such a method of social work, where one appeals rather not by words, but by presence and example, in parallel with conducting spiritual warfare aimed at obtaining freedom. Among the necessary conditions in the application of this method are: equality between the two parties of aid, the ability to avail failures and deficits, humility, courage, perseverance and a sense of humor. An important field of giving good example is
\end{abstract}


pokora, odwaga, wytrwałość oraz poczucie humoru. Istotnym polem dawania dobrego przykładu jest staranna i rzetelna praca. Chociaż sam br. Jerzy stosował tę metodę wyłącznie w obrębie schronisk dla bezdomnych, gdzie sam pracował, nadaje się ona do uniwersalnego zastosowania na rozmaitych polach prowadzenia pracy socjalnej indywidualnego przypadku.

\section{Słowa kluczowe: metody pracy}

socjalnej, towarzyszenie duchowe. a careful and diligent work. Although $\mathrm{Br}$. Jerzy applied this method only within the shelters for the homeless, where he worked, it is suitable to make universal applications on various fields where case work is conducted.

Keywords: Social work methods, spiritual accompaniment.

Brat Jerzy Adam Marszałkowicz, urodzony w roku 1931, jest kluczową postacią wśród założycieli Towarzystwa Pomocy im. św. Brata Alberta (TPBA) ${ }^{1}$ i praktykiem, który kilkadziesiąt lat własnego życia poświęcił służbie ludziom bezdomnym. Jest on duchownym archidiecezji wrocławskiej bez święceń prezbiteriatu, stąd utarło się tytułować go „bratem”, aczkolwiek ten tytuł może mylnie sugerować, że jest on zakonnikiem. Decyzją kardynała Henryka Gulbinowicza z roku 1981 br. Jerzy został skierowany do pracy w Towarzystwie Pomocy i obecnie, już na prawach emeryta, nadal mieszka w schronisku dla bezdomnych, w którym pracował przez wiele lat, w Bielicach, w województwie opolskim $^{2}$. Pisma br. Jerzego to głównie referaty wygłaszane przy okazji rozmaitych spotkań, a następnie rozpowszechniane $\mathrm{w}$ formie kserokopii lub poprzez strony internetowe.

W wypowiedziach br. Jerzego nigdzie nie pojawia się termin „metoda pracy socjalnej”. Praca socjalna w świadomości wielu osób ma pozostawać w wyłącznej kompetencji urzędników zatrudnionych w ośrodkach pomocy społecznej i z tego punktu widzenia trudno wyczekiwać, co na jej temat miałby do powiedzenia praktyk ze schroniska dla bezdomnych. Podobny sposób myślenia został jednak zdecydowanie odrzucony w gronie realizatorów systemowego

1 Sam br. Jerzy sprzeciwia się przypisywaniu mu funkcji postaci kluczowej i utrzymuje, że był jedynie iskierką. Ponieważ jednak sam jestem jednym z członków - założycieli TPBA, pozwalam sobie na prawo do własnej oceny. W dalszym ciągu artykułu, jeżeli nie ma odwołania do konkretnego tekstu, oznacza to, że opieram się na osobiście usłyszanych słowach i własnych obserwacjach.

2 W roku 2016 br. Jerzy Marszałkowicz został 24 czerwca uhonorowany Nagrodą Wrocławia, zaś 9 grudnia nagrodą specjalną „Dla Dobra Wspólnego” wręczoną przez Prezydenta RP Andrzeja Dudę. 
projektu „Gminny standard wychodzenia z bezdomności”; w sporządzonym w roku 2011 raporcie z fazy diagnozy czytamy, że w rozmaitych placówkach pomocy bezdomnym w Polsce była prowadzona praca socjalna, aczkolwiek zazwyczaj ani bez jej finansowania ze strony publicznej czy samorządowej, ani też jako podstawowa forma prowadzonej pomocy, gdyż dosyć skąpe fundusze były kierowane tylko na interwencję kryzysową, zazwyczaj ograniczającą się do zapewnieniem noclegu, odzieży i skromnego wyżywienia. Wśród stosowanych metod pracy socjalnej (wszystkich mieszczących się wśród case work - prowadzenia indywidualnego przypadku) autorzy raportu wymieniali mentoring, asystenturę, jobcoaching, lifecoaching, metodę towarzyszenia (akompaniowanie) i rzecznictwo. Spośród wymienionych za najbardziej typową dla TPBA uznali oni metodę towarzyszenia ${ }^{3}$.

Wspomniany wyżej głos nie zamyka sporu, czy w schroniskach dla bezdomnych jest, czy też nie jest prowadzona praca socjalna. Można poddawać w wątpliwość, czy działalność tam prowadzona jest zaplanowana, można też wskazywać na brak stosownej dokumentacji. Tym niemniej stawiam hipotezę, że i sam br. Jerzy, i jego współpracownicy oraz naśladowcy, działają według specyficznej metody pracy socjalnej, gdzieniegdzie nazywanej metodą towarzyszenia duchowego. Będę niżej próbował tę metodę zdefiniować.

\section{Towarzyszenie a towarzyszenie duchowe}

W TPBA powszechne stosowanie terminu „metoda towarzyszenia” ma miejsce dopiero od roku 2005, kiedy to przyjęta ona została na użytek Punktów Aktywizacji Bezrobotnych (PAB), prowadzonych w ramach projektu „Wyprowadzić na prostą"4. Termin ten już kilka lat wcześniej uzyskał popularność w środowiskach polskiego Caritas ${ }^{5}$, a przyjęty został na wzór metody pracy z osobami starającymi się wyjść $\mathrm{z}$ bezrobocia wzorowanej na działalności francuskiej Secours Catholique departamentu Seine-Saint-Denis, gdzie przyjmuje się bezrobotnych, wysłuchuje ich i towarzyszy im w dalszej drodze mającej za-

3 Raport z fazy diagnozy. Kondycja i dobre praktyki pomocy ludziom bezdomnym w sześciu obszarach: streetworking, praca socjalna, mieszkalnictwo i pomoc doraźna, partnerstwa lokalne, zdrowie, zatrudnienie i edukacja, red. R. Stenka, Gdańsk 2011, s.134.

4 Projekt realizowany był przez TPBA i Caritas w latach 2004-2008, a finansowany z „Equal”; zob.: A. Wiktorska-Święcka, E. Oleniacz-Czajka, Ocena metody towarzyszenia na podstawie realizacji projektu Wyprowadzić na prosta, w: Wyprowadzić na prosta, red. A. Wiktorska-Święcka, Wrocław 2008, s. 286-289.

5 S. Słowik, Rozwój metody towarzyszenia w Polsce, w: Wyprowadzić na prostą..., dz. cyt., s. 141-144. 
kończyć się pomyślnym znalezieniem zatrudnienia. Jednak w TPBA już dużo wcześniej używało się terminu „towarzyszenie”, odnosząc go tak do pracy br. Jerzego, jak i św. Brata Alberta, który na przełomie XIX i XX wieku rozwinął pomoc bezdomnym i ubogim. Karol Wojtyła w swej sztuce Brat naszego Boga wkłada w jego usta słowa ,ja pójdę za nimi” ${ }^{-}$- w trakcie sporu z rewolucjonistą, w kontekście tego, iż nie zamierza kierować bezdomnymi i ubogimi, lecz być ich cichym towarzyszem. Temu samemu poświęcone są słowa przypisywane Bratu Albertowi: „My nie mamy nad ubogimi władzy żadnej i mieć jej nie chcemy, nie jesteśmy ich przełożonymi, ale towarzyszami. Nie mówimy kazań, nie narzucamy się z naszymi poglądami, jedynie żyjemy z nimi. Chodzi nam o to, by się nie wyróżniać, a świecić jedynie czynem i przykładem. A ten przykład powinien być tak zbliżony do otaczających warunków, tak pokorny, tak nędzny, aby nie raził swoim stylem, nie właził w oczy, nie upokarzał" .

Br. Jerzy Marszałkowicz jedyne, czego zawsze pragnął, to naśladować Brata Alberta, stąd nie potrzebuje szukać nowej nazwy dla stosowanej przez siebie metody pracy socjalnej. Uważam jednak, że warto dla tej metody zastosować określenie „towarzyszenia duchowego”, co jednak nie oznacza, aby chodziło o coś lepszego od "metody towarzyszenia” bez przymiotnika „duchowy”. Gdy proponuję tę nazwę, pozostając wierny dziedzictwu oraz terminom używanym niegdyś przez samego Brata Alberta, próbuję raczej zastosować zindywidualizowane określenie specyficznej metody stosowanej przez br. Jerzego, idąc za niektórymi osobami starającymi podejmować pracę w jego stylu, co na przykład ma miejsce w noclegowni dla bezdomnych mężczyzn przy ul. Małachowskiego we Wrocławiu ${ }^{8}$. W tym miejscu dotykam powodu napisania niniejszego artykułu. Nie chodzi mi o to, aby cokolwiek ulepszać w pracy br. Jerzego, albo też wmawiać mu, że powinien on używać innej terminologii, niż to czynił przez całe swe długie życie. Chodzi mi o tych, którzy w dobrej wierze go naśladują, aby znaleźli metodyczne ujęcie zasad tej pracy.

\section{Definicja metody towarzyszenia duchowego}

Chciałbym podać, na ile to możliwe, istotne cechy metody stosowanej przez br. Jerzego w kształcie, który dalej dawałby się zaadaptować do różnych rodzajów prac, nie tylko w schroniskach i noclegowniach dla osób bezdomnych. Uniwer-

\footnotetext{
K. Wojtyła, Brat naszego Boga, Wrocław 2003, s. 104.

M. Winowska, Znieważane oblicze. Opowieść o św. Bracie Albercie, Kraków 2001, s. 177.

Chodzi tu o pracę wolontariuszy z udziałem Aleksandra Kowalskiego i ks. Ryszarda Zawadzkiego.
} 
salne sformułowania będą później wymagały dalszych uściśleń i uzupełnień, gdyby je przekładać na szczegółową metodykę pracy w poszczególnych miejscach, opisy modeli kompetencyjnych oraz regulaminy.

Proponuję przyjąć następującą definicję: towarzyszenie duchowe jest metodą pracy socjalnej, gdzie przemawia się mniej słowami, a bardziej obecnością i własnym przykładem, z prowadzeniem walki duchowej mającej na celu uzyskanie wolności. Wśród nieodzownych warunków przy stosowaniu tej metody są: równość między obydwoma stronami pomocy, umiejętność wykorzystywania porażek i deficytów, pokora, odwaga, wytrwałość oraz poczucie humoru. Istotnym polem dawania dobrego przykładu jest staranna i rzetelna praca.

W powyższych sformułowaniach kryje się wiele pułapek. Przykładowo, nietrudno sobie wyobrazić pracownika socjalnego, który poczuje się zwolniony z pogłębiania własnej wiedzy, bo słyszy, iż ma jedynie promieniować osobistym przykładem, co wydaje mu się wyjątkowo łatwe przy własnym narcystycznym samozadowoleniu. Inny przykład błędnego zrozumienia moich intencji to podjęcie walki duchowej z człowiekiem, a nie z grzechem. Niżej spróbuję podać kilka uściśleń, które powinny dopomóc w lepszym zrozumieniu opisywanej, trudnej metody.

Br. Jerzy przekazał, jak to jeden $\mathrm{z}$ bezdomnych przyjmowanych do schroniska powiedział: „ja jestem tylko fragmentem człowieka”. Praca z ludźmi wyprowadzanymi z głębokiej bezdomności to naprawdę poważne wyzwanie i nie jest tu łatwo dać rzeczywiste wzmocnienie. Oczywiście, każdy człowiek jest inny i nie ma tu miejsca na jedną zuniformizowaną receptę. Wszystko, co znajduje się w niniejszym artykule, nie wzbrania przed stosowaniem rozmaitych metod i strategii; pluralizm dróg jest ze wszech miar pożądany i nie ma tu argumentów, iż droga br. Jerzego jest to jedyna, czy też najlepsza. Chcę tu jedynie opisać, jak stara się pracować pewien sędziwy już dziś człowiek, który większość swego życia poświęcił służbie bezdomnym. Czy ktoś zechce z tego wynieść dla siebie jakąś korzyść, pozostaje jego wolną decyzją.

\section{Przemawianie własnym przykładem}

Br. Jerzy wśród punktów rachunku sumienia osób pomagającym bezdomnym zaleca stawianie sobie pytania: „Czy rozumiem, że moją rolą jest dawanie ewangelicznego świadectwa miłości i miłosierdzia, nie oglądając się na to, czy moje działanie przyniesie sukces, czy też nie? Czy umiem zostawić tę sprawę

9 Film przygotowany na galę w Narodowym Forum Muzyki we Wrocławiu dnia 4.11.2016 z okazji 35-lecia TPBA, realizacja Dariusz Dobrowolski. 
Panu Bogu"10? Można w tym dostrzec nawiązanie do postawy Brata Alberta, który dawał nie tylko to, co się ma, ale i czym się jest, jak to relacjonuje socjolog Marek Rymsza ${ }^{11}$.

Powyższa wypowiedź br. Jerzego rozwiewa ewentualne wątpliwości, iż nie chodzi tu o motywowaną samozadowoleniem chęć promieniowania własną wyobrażoną doskonałością duchową. Kto by się kierował taką postawą, może co najwyżej administrować ludźmi, ale nie będzie tu niczego wspólnego z pracą czy to br. Jerzego, czy samego Brata Alberta. Chodzi natomiast o powściągliwość w słowach, unikanie jałowego moralizowania, a także nieuleganie własnym ambicjom bycia skutecznym. Takie ambicje zazwyczaj stają się przeszkodą $\mathrm{w}$ rzeczywistym spotkaniu $\mathrm{z}$ drugim człowiekiem. Br. Jerzy radzi, aby jak najlepiej robić swoje, zaś sprawy skuteczności zostawiać Panu Bogu. Tak więc dawanie przykładu własną osobą wiąże się tu ze swego rodzaju wycofaniem i pokornym uznaniem własnej niewystarczalności; ponieważ prawdopodobieństwo osiągnięcia sukcesu jest niewielkie, należy wykorzystać wszelkie dostępne środki, a w tym rzucić na szalę i swoje własne życie. To w tym kontekście Brat Albert nakazywał stawać się chlebem, który leży na stole i z którego każdy może sobie urwać, ile zechce.

Klucz przy ukazywaniu, czym się jest, to być wiarygodnym, i takim zawsze był oceniany br. Jerzy, idący tu za Bratem Albertem ${ }^{12}$. Istotą wiarygodności jest brak zafałszowania, zgodność pomiędzy tym, co się głosi, a jak się pracuje i żyje. Praca metodą towarzyszenia duchowego może być cicha, pozbawiona tyrad i pouczeń, bo przemawia się mniej słowami, a bardziej własną postawą, własnym przykładem. Chodzi w niej nie tyle o to, by kogoś do czegoś przekonać, ile o to, by kogoś do czegoś porwać. Towarzyszenie winno się wiązać z oszczędnością słów.

Miłosierdzie jest $\mathrm{z}$ jednej strony bezwarunkowe, ale $\mathrm{z}$ drugiej strony wymagające. Aby rozwikłać sprzeczność zawartą w powyższym stwierdzeniu, należy przejść na poziom dawania przykładu własnym życiem. Ten, kto wiele wymaga od siebie samego, pokazuje i innym jako wzór, iż należy od siebie wiele wymagać. To dlatego br. Jerzy zalecał, by w rachunku sumienia pytać się: „Czy rozróżniam, że wyrozumiałość jest cnotą (np. wobec starców, kalek i chorych, chociażby podpadli), a pobłażliwość jest wadą albo nawet grzechem (np. niekaranie ciężkich przestępstw i wykroczeń)?"'13.

10 J. Marszałkowicz, Rachunek sumienia prowadzacych schroniska, noclegownie i inne placówki TPBA, nr 12.

11 M. Rymsza, Brat Albert jako prekursor pracy środowiskowej $z$ bezdomnymi na ziemiach polskich, „Głos Brata Alberta” 2014, nr 1 (76), s. 28.

12 M. Rymsza, Brat Albert jako prekursor..., dz. cyt., s. 28.

13 J. Marszałkowicz, Rachunek sumienia prowadzacych..., dz. cyt., nr 19. 


\section{Prowadzenie walki duchowej}

Być może, zamiast groźnie brzmiącego terminu „walka duchowa”, lepiej byłoby w definicji metody towarzyszenia duchowego używać słowa „modlitwa”. Ku temu skłania wypowiedź br. Jerzego: „Jeżeli ta praca nie będzie podparta wytrwałą modlitwą, może dojść do tego, że z niechęcią będziemy dźwigać ciężar podjętej pracy i powoli odczuwać zespół wypalenia. Zamiast widzieć w podopiecznych zagubione dzieci Boże, które Bóg otacza miłością i miłosierdziem, zaczynamy widzieć w nich: leniów, łazęgów, żebraków, ochlaptusów alkoholowych, naciągaczy, kryminalistów i oszustów. Tak więc zamiast patrzeć na nich oczyma wiary, nadziei, miłości, patrzymy na nich - jak w bajce Andersena - oczyma, do których wpadło szkło i widzimy ich wtedy w skrzywionym zwierciadle. Tracimy wtedy często nadzieję, że przynamniej z niektórych podopiecznych wykrzeszemy jakąś iskrę opamiętania i nawrócenia. Zamiera też czasem w naszej duszy współczucie, litość, miłość i miłosierdzie"14. W prosty i zrozumiały sposób jest tu wyjaśnione, że bez wytrwałej modlitwy zaniknie wrażliwość i miłość potrzebna w pracy metodą towarzyszenia duchowego.

Modlitwę należy również kierować w intencji osoby, której się pomaga. „Trzeba za wzorem św. Brata Alberta stać się bratem ludzi bezdomnych, mniej lub więcej utożsamić się z nimi i nieść im bezinteresowną pomoc, dawać dobry przykład i walczyć pokutą i modlitwą ze złymi mocami, które tkwią w wielu wykolejonych i zdeprawowanych bezdomnych"15. Tu br. Jerzy wprowadził nowy, istotny element, poza samą modlitwą - pokutę. Opisał w ten sposób to, co przez całe życie sam na co dzień czynił względem osób, do których kierował własną pomoc. I tutaj już właściwym staje się termin „walka duchowa”. W samym sercu metody towarzyszenia duchowego jest świadomość, że w każdym człowieku toczy się walka ze złymi mocami. Mieszkańcy schronisk mogą bardzo wiele opowiedzieć o tym, jak stykali się z tymi mocami, na przykład gdy wbrew własnym chęciom krzywdzili innych ludzi, w tym nieraz dzieci i współmałżonka.

Nie zrozumie się metody br. Jerzego, gdy w duchu XIX-wiecznego pozytywizmu będzie negowało się istnienie duchowego wymiaru życia. Warto mieć świadomość, że powstało już wiele opracowań naukowych na temat wątków duchowości w pracy socjalnej, co jest poza zakresem niniejszego artykułu ${ }^{16}$. Od ponad 80 lat kwestia walki duchowej jest też standardowym elementem tera-

14 J. Marszałkowicz, Referat na otwarcie Zebrania Zarządu TPBA Dębicy w dniu 20.02.2009.

15 J. Marszałkowicz, Bezdomni w nowej rzeczywistości, referat z czerwca 2013, https:// docs.google.com/file/d/0B85s1tT6IvMQSmZlT0RLSzZ4bGs/edit (15.12.2016).

16 Jako przykładową publikację z tej dziedziny podajmy B. Crisp, Spirituality and Social Work, Farnham 2010. 
pii uzależnień prowadzonej przez Anonimowych Alkoholików. Długie lata doświadczeń tego ruchu wskazują, iż rozwój życia duchowego jest dobrym rozwiązaniem pozwalającym uniknąć tego, by, jako osoba unikająca „zapicia”, nie być - mówiąc kolokwialnie - siedzącym „ze ściśniętym tyłkiem i zaciśniętymi zębami”. Rozwój duchowy i nierozłączna z tym walka duchowa są sposobem na przemianę swego codziennego postępowania ${ }^{17}$. Jest to walka o wolność wewnętrzną, i ku temu samemu zawsze zmierzały modlitwy i posty podejmowane przez br. Jerzego w intencji osób, którym pomagał.

Należy tu zwrócić uwagę, że w powyższych działaniach nie chodzi o naruszanie czyjejkolwiek wolności sumienia. W wywiadzie z października 2010 roku br. Jerzy powiedział, że prowadzona przez niego pomoc nie jest nastawiona na czyjekolwiek nawrócenie. „Po prostu jest uczynkiem miłosiernym, który sam za siebie mówi. Nigdy nie myślałem, że podając komuś talerz zupy, narzucam mu wolę nawrócenia. Nędzarze, widząc ogromny krzyż nad seminarium, bez lęku przychodzili do mnie, bo wiedzieli, że Ten Znak oznacza miłosierdzie”. I nieco dalej „Ja nie wnikam w dusze tych ludzi”"

Walka prowadzona w ramach metody towarzyszenia duchowego przypomina zawarte w dramacie Karola Wojtyły Brat naszego Boga wezwanie Brata Alberta: „daj się kształtować miłości” ${ }^{19}$. Cierpliwa posługa br. Jerzego zawsze szła właśnie po tej drodze - by poprzez miłość podnoszącą godność człowieka powiększać wolność ludzi znajdujących się w stanie wykluczenia społecznego. Chodzi tu jednak o trudne, głębokie rozumienie wolności jako umiejętności czynienia dobra, a nie o poprzestanie na łatwej samowoli. Aby móc „zarażać” takim rozumieniem wolności, trzeba inwestować we własną wolność. Stawką jest wolność osoby bezdomnej, zazwyczaj spętanej uzależnieniami, ale również i wolność osoby pomagającej. Nikt, łącznie $z$ br. Jerzym, nie jest pozbawiony wad i grzechów, ale gdy prowadzi z nimi walkę, wówczas nie pozwala im przygnieść swej własnej wolności; ta zaś jest potrzebna do tego, by lepiej pomagać drugiemu człowiekowi. Wyobraźmy sobie, że w schronisku pracownik albo wolontariusz są targani wewnętrznym gniewem, a może zazdrością - te dążności ograniczają ich wolność duchową, a przy tym skuteczność pracy.

17 Anonimowi Alkoholicy odwołują się do Boga, jakkolwiek jest On pojmowany. Zastosowanie tak otwartej formuły nie stanowi przeszkody, aby przebudzić się duchowo i uwalniać od wad charakteru. Za Carlem Gustawem Jungiem zwracają się ku rzeczywistości duchowej w myśl hasła spiritus contra spiritus; zob.: dwanaście kroków AA na: http://www. aa.org.pl/main/viewpage.php?page_id=4 (15.12.2016).

18 R. Oktaba, Nieopublikowany wywiad z Jerzym Marszałkowiczem przeprowadzony w październiku 2010.

19 K. Wojtyła, Brat naszego..., dz. cyt., s. 69. 
Andrzej Ptak, wychowanek br. Jerzego i jeden z pracowników TPBA, mówi czasem o swoim mistrzu: człowiek, którego nie ima się zło. Osoby znające br. Jerzego wiedzą, że ma on pewną cechę, która zazwyczaj jest interpretowana jako rodzaj tiku psychicznego - gdy to nagle przerywa wypowiedź i przez chwilę z półotwartymi ustami porusza głową, zanim ponownie wraca do wypowiedzi. Jak to mi jednak sam powiedział, takie dziwne zachowanie wynika $\mathrm{z}$ tego, że przychodzi do niego jakaś niewłaściwa myśl i potrzebuje tej chwili czasu, aby ją przezwyciężyć. I to właśnie dzięki temu nie ima się go zło - bo nigdy nie przestaje z nim walczyć.

Br. Jerzy nie używa terminu „walka duchowa”, lecz opisuje ją prostymi słowami: „Chyba każdy z działaczy, opiekunów i pracowników Schroniska ma swoje cierpienia, zmartwienia, kłopoty, przemęczenia, ale powinien przezwyciężać siebie i pomagać podopiecznym znajdującym się w jeszcze większym cierpieniu i bezradności. Zawsze możemy i sobie i innym pomóc w ten sposób, że będziemy innym pomagać $\mathrm{w}$ cierpieniu i przezwyciężaniu lęku. Zawsze możemy - nawet w swojej bezradności - przybliżać Pana Boga swoją postawą, modlitwą i obecnością"20.

\section{Równość}

Wyżej przytoczyłem już wypowiedź br. Jerzego, iż należy stać się bratem ludzi bezdomnych ${ }^{21}$. Wypowiedź ta wskazuje na niezbędny element metody towarzyszenia duchowego - aby prowadzona ona była z pozycji równości obu stron pracy socjalnej. Sam br. Jerzy odnosi się do równości w następujących punktach postulowanego rachunku sumienia: „Czy prowadzący te placówki starają się zniżać i jednoczyć z podopiecznym po bratersku, czy też uważają się za wyższą klasę rządzącą podopiecznymi jak przedmiotami?”22, „Czy mam świadomość, że najważniejsze jest ludzkie spotkanie z ubogim bratem, a dopiero za tym powinno iść dawanie mu rzeczy potrzebnych do życia”23? „Czy nie mam wygórowanych ambicji i czy staram się po bratersku odnosić do ubogich podopiecznych i czy sam staram się praktykować ubóstwo zgodnie z moim

20 J. Marszałkowicz, Problemy działaczy, opiekunów i pracowników oraz podopiecznych Schronisk św. Brata Alberta i innych placówek TPBA, 13.05.2006.

21 J. Marszałkowicz, Bezdomni w nowej..., dz. cyt.

22 J. Marszałkowicz, Rachunek sumienia: czy do wypetnienia testamentu Brata Alberta wystarczy szyld z jego imieniem?, „Tygodnik Powszechny” 2002, nr 25 (2763).

23 J. Marszałkowicz, Rachunek sumienia prowadzacych..., dz. cyt., nr 11. 
stanem, pamiętając o słowach Brata Alberta: «Kto chce służyć ubogim, musi sam być ubogi, bo inaczej tę służbę porzuci»?"24.

Br. Jerzy stawia na prawdziwą i podkreślaną równość wszystkich korzystających z pomocy i działających w duchu św. Brata Alberta, bez podziału na „my” i „oni”. Ta równość wynika z równości wszystkich ludzi wobec Boga, a nie $\mathrm{z}$ tego, jakoby wszyscy mieli te same talenty i te same obowiązki. Bycie dla nich bratem oznacza oddanie siebie w całości i bez reszty; jak postawę br. Jerzego ujął ks. prof. Jan Śledzianowski: „wyzbył się wszystkiego, zamieszkując z bezdomnymi” ${ }^{25}$. W cytowanym wyżej wywiadzie na pytanie „Dlaczego podopieczni nazywają Brata tatą?” odpowiedział: „Myślę, że dlatego, że dzielę ich los. Mieszkam razem z nimi, jem to co oni, jestem z nimi na co dzień.” Na pytanie „Dlaczego od początku istnienia schronisk aż dotąd mieszka Brat $\mathrm{z}$ bezdomnymi we wspólnym pokoju?” odpowiedział: „Mieszkam we wspólnym pokoju, bo chciałem dzielić warunki życia moich podopiecznych. Prócz tego są jeszcze inne racje. Bo jeżeli ja bym mieszkał osobno, to bym nie wiedział, co się dzieje w schronisku, jakie awantury się w nocy dzieją"26. Br. Jerzy sam więc, z własnej woli, przyjął sposób życia bezdomnych - podopiecznych schroniska, aby w ten sposób móc lepiej trafić do nich ze swoją pomocą.

Ubóstwo br. Jerzego, po części naśladowane przez wielu działaczy i pracowników TPBA, nie jest powiązane ze stanem konta bankowego, lecz - nade wszystko - ze świadomością równości oraz staraniami, by przybliżyć własny styl życia do tego, jak żyją sami ubodzy. Pomoc nie ma być czyniona „z łaski” (z pogardą dla jej beneficjentów), lecz jako akt braterstwa. Postawa w duchu Brata Alberta nakazuje poszukiwanie jedności z innymi ludźmi, w tym z ubogimi i bezdomnymi. I tylko przy świadomości równości praca socjalna może być zakwalifikowana jako prowadzona metodą towarzyszenia duchowego.

\section{Umiejętność wykorzystywania porażek i deficytów}

Kolejny element metody towarzyszenia duchowego to twórcza umiejętność wykorzystywania własnych porażek i deficytów. Ten element ma szczególne znaczenie $\mathrm{w}$ pracy socjalnej $\mathrm{z}$ osobami wyprowadzanymi ze stanu głębokiego wykluczenia społecznego. Br. Jerzy wskazuje na pozytywną stronę trudności:

\footnotetext{
24 J. Marszałkowicz, Rachunek sumienia prowadzacych..., dz. cyt., nr 14.

25 J. Śledzianowski, Towarzystwo Pomocy im. św. Brata Alberta a bezdomność, Wrocław 1995, s. 31.

26 R. Oktaba, Nieopublikowany wywiad..., dz. cyt.
} 
„Co zbliżyło Brata Alberta do bezdomnych? Po pierwsze, że był sierotą już od dziecka, nie miał własnego domu, a także to że stracił nogę, stał się kaleką. Każdy kaleka współczuje ludziom, którzy też są pewnego rodzaju kalekami - czy fizycznymi, czy psychicznymi. Własne upośledzenie zbliżyło Brata Alberta do upośledzonych, wzgardzonych. I ja też jestem poniekąd upośledzony"27. Zapewne odniósł się tu do tych własnych cech, które na pewnym etapie zagrodziły mu dostęp do święceń kapłańskich. I rzeczywiście, wskazuje się, jak wielką korzyść Brat Albert wyciągnął z własnych porażek i deficytów. Reżyser Krzysztof Zanussi komentuje: „Kruchy neurastenik przeobraził się pod koniec życia w człowieka o tak niebywałej odporności na niepowodzenia, że nie sposób uwierzyć w jego wcześniejsze załamania" ${ }^{28}$. W tych słowach można odkryć, że to, co na pozór było słabością Brata Alberta - w tym skrupuły i problemy psychiczne, w istocie posłużyło mu jako dobro, na którym zbudowane zostało wielkie dzieło służby albertyńskiej. Na to samo wskazuje Rymsza: trudne doświadczenia życiowe św. Brata Alberta - sieroctwo, kalectwo, porażki, niezrozumienie, upokorzenia, choroba psychiczna - wewnętrznie przepracowane, były podstawą radykalnego wyboru drogi pomagania, a jednocześnie łagodnego, wyrozumiałego podejścia do ludzi marginesu społecznego. Powszechnie uderzało jego pogodne usposobienie, prostota w obejściu, umiejętność słuchania, urok osobisty ${ }^{29}$.

Dobrze prowadzona praca socjalna bazuje na zasobach, nie na deficytach. Jednak w przypadku metody towarzyszenia duchowego możliwe jest traktowanie deficytów jako zasobów. I św. Brat Albert, i br. Jerzy wykorzystywali własne deficyty, własne słabości jako swą siłę. Jest tu pewien paradoks, niełatwy do wyjaśnienia bez odwołań do sfery religijnej. Ale i bez tego da się go zrozumieć. Najgorzej pomagać temu pracownikowi socjalnemu, który ma wysokie wyobrażenie o własnych kompetencjach oraz umiejętnościach, bo aż się rwać będzie do tego, by ludziom tanim kosztem meblować ich życie. Dużo łatwiej, jeżeli pracownik socjalny ma głębokie poczucie własnej grzeszności - może wtedy z empatią odnosić się do problemów drugiego człowieka i pozostawiać mu jak najwięcej wolnego pola, by ten własnymi siłami rozwiązywał własne problemy, lub też by odkrywał religijny wymiar ofiarowywania własnej słabości i niewystarczalności. W metodzie towarzyszenia duchowego idealny pracownik

\footnotetext{
$27 \quad$ Wywiad z Jerzym Marszałkowiczem w Radiu Maryja, 15.12. 2010.

28 Z wypowiedzi Krzysztofa Zanussiego podczas przeglądu filmów o bezdomności w Dolnośląskim Centrum Filmowym we Wrocławiu dnia 21.12.2011.

29 M. Rymsza, Od akcji dobroczynnej do pracy środowiskowej - działalność Brata Alberta $w$ środowisku ludzi bezdomnych w Krakowie i innych miastach polskiej Galicji na przełomie XIX i XX wieku, w: Praca środowiskowa w Polsce - tradycja i teraźniejszość, red. M. Rymsza, Warszawa 2014, s. 100.
} 
socjalny to taki, o którym nikt nie wie, że ten wykonuje pracę socjalną. Należy bowiem nie tyle argumentować, przekonywać o tym, że upadek nie przekreśla szans na wyzwolenie, co raczej umieć własnym przykładem to pokazywać. Tak przynajmniej czyni br. Jerzy: kto wejdzie z nim w bliższy kontakt, dostrzeże, jak wiele on zyskał, przezwyciężając to, co sam określa jako własne upośledzenie.

Ani sam br. Jerzy, ani jego najbliżsi wychowankowie nie sprawiają wrażenia osób idealnych, świecących swą perfekcyjnością. Taka jest jednak cena stosowania metody towarzyszenia duchowego, w której nie należy onieśmielać własną doskonałością, lecz raczej podnosić na duchu własną niedoskonałością. Ten sięga do sfery duchowej, kto sobie nie radzi, kto jest świadom swej niewystarczalności; jednak niezliczone świadectwa osób potwierdzają, że umiejętne wejście do sfery duchowej daje wymierne korzyści pozwalające przezwyciężać trudności życia. Aby służyć jako przewodnik na tej drodze, trzeba samemu doświadczyć niewystarczalności; szczególnie wiele potrafią pokazać ci pracownicy i terapeuci, którzy sami wyszli z uzależnień czy wykluczenia społecznego, na co jednym z przykładów są wspomniani wcześniej instruktorzy ruchu Anonimowych Alkoholików.

\section{Pokora, odwaga, wytrwałość, poczucie humoru}

Kolejne elementy metody towarzyszenia duchowego to pokora, odwaga, wytrwałość i poczucie humoru. Br. Jerzy napisał: „Mimo naszych słabości i wad musimy po bratersku i z dobrocią odnosić się do naszych podopiecznych, którym mamy służyć całym naszym życiem - stosownie do stanu każdego z nas. Oni wyczują błyskawicznie, czy szanujemy ich i kochamy, czy świecimy dobrym przykładem i wtedy będziemy stanowić dla nich autorytet" ${ }^{30}$. W tej trudnej pracy łatwo ujawnia się wszelka hipokryzja; w wymiarze duchowym człowiek staje się przezroczystym. Stąd br. Jerzy zachęca, by naprawdę szanować i kochać osoby, którym się pomaga, a przy tym z pokorą przyznawać się do własnych słabości i wad.

W pomocy bezdomnym trzeba umieć odłożyć na bok pośpiech i pragnienie sukcesu. W cytowanym wywiadzie na pytanie „Czego potrzeba, aby wytrwać w pracy z bezdomnymi?” br. Jerzy odpowiada: „Poświęcenia i determinacji”. A gdzie indziej: „Przez nadzieję nie powinniśmy ustawać w wysiłkach, aby pomagać podopiecznym, chociaż by to było po raz trzeci, piąty czy dziesiąty, bo mamy nadzieję, że może tym razem nasza pomoc będzie skuteczna.

30 J. Marszałkowicz, Czym jest Wspólnota Albertyńska działająca w ramach TPBA?, 17.05.2008. 
[...] Powinniśmy poświęcać im swój czas a nierzadko należny odpoczynek. Powinniśmy wysłuchiwać ich z cierpliwością, gdyż czasem skarżą się, że nikt nie chce ich wysłuchać. Przez miłość bliźniego przebaczajmy im, że czasem nas skrzywdzą, czasem nas obmówią, czasem nam ubliżą albo zachowują się wobec nas całkiem obojętnie i z niechęcią"31. Obok wytrwałości istotna jest tu i odwaga, o której sam br. Jerzy nie wspomina, ale która jest potrzebna w pracy wśród bezdomnych.

Kolejnym, do czego wzywał br. Jerzy, były cierpliwość, odporność na obelgi i potwarze. Albertyński styl pracy zakłada stałą gotowość do wybaczania. Br. Jerzy pisał: „przez miłość bliźniego przebaczajmy im, że czasem nas skrzywdzą, czasem nas obmówią, czasem nam ubliżą albo zachowują się wobec nas całkiem obojętnie i z niechęcią"32.

Br. Jerzy wzywał też, aby nie tracić poczucia humoru. „Ostatnią, ale nie najmniejszą, sprawą jest to, aby działacze Schroniska dostarczali podopiecznym - w miarę możliwości - pewnych pozytywnych i radosnych impulsów w ich szarym, a czasem nudnym pobycie w Schronisku. [...] Pracownicy mimo swoich licznych obowiązków powinni mieć czas dla podopiecznych, aby ich wysłuchać, czasem pocieszyć i rozweselić"33.

\section{Rzetelna praca}

Wszędzie tam, gdzie br. Jerzy prowadził pracę na rzecz bezdomnych, starał się też organizować pracę samych bezdomnych. Odwoływał się w tym do przykładu Brata Alberta, o którym pisał, że ten „był nowatorem, różniącym się od innych działaczy miłosierdzia przez to, że żądał od swoich podopiecznych, aby w miarę ich możliwości sami zapracowali na swoje utrzymanie w przytulisku przez pracę tam organizowaną" ${ }^{34}$. Czasem praca organizowana przez br. Jerzego to była hodowla świń, czasem klejenie kopert. Wątła skala tych działań wynikała jedynie z trudności organizacyjnych oraz przeciążenia rozmaitymi obowiązkami. Gdyby to było możliwe, tworzyłby własne zakłady pracy, w których bezdomni mogliby się spotykać z życzliwą atmosferą i gdzie mogliby przezwyciężać własną samotność - coś na wzór wytwórni mebli giętych, którą niegdyś Brat Albert uruchomił na krakowskim Kazimierzu.

31 J. Marszałkowicz, Oświadczenie Wspólnoty Albertyńskiej co do tematu co to znaczy wykonywać prace w duchu św. Brata Alberta z dnia 28.06.2006.

32 J. Marszałkowicz, Oświadczenie Wspólnoty Albertyńskiej..., dz. cyt.

33 J. Marszałkowicz, Problemy działaczy..., dz. cyt.

34 J. Marszałkowicz, Święty Brat Albert patrzał na bezdomnych oczyma wiary. 
Jak twierdził br. Jerzy, „człowiek z natury swej chce czuć się potrzebny. Ta potrzeba przyczynia się do rozwoju osoby ludzkiej. Dlatego wielkim zadaniem pracowników jest szukanie i wynajdywanie pracy i zajęć dla podopiecznych. Dla zdrowych trzeba wynajdywać prace, które również przynosiłyby dochód dla Schroniska. Dla chorych i kalekich trzeba wynajdywać albo jakieś całkiem lekkie prace, albo zajęcia domowe, czy to przy utrzymaniu porządku, czy przy sporządzaniu posiłków. Prawdą jest bowiem według Pisma Świętego, że «ptaki są stworzone do latania, a ludzie do pracy». Wynajdywanie pracy i zajęć dla podopiecznych jest więc obowiązkiem miłości bliźniego, bo człowiek w pracy się rozwija i nie traci sensu swojej egzystencji, czuje się potrzebny" ${ }^{35}$. Z mocą podkreślał, że placówki noszące imię św. Brata Alberta nie mają być „domami wczasowymi, gdzie mieszkańcy nie są zobowiązani do żadnej pracy"36. W rachunku sumienia radził umieszczać pytanie: „Czy staram się według możności wyszukiwać prace dla podopiecznych, którzy do pracy są zdolni - czy to na zewnątrz, czy też wewnątrz Schroniska celem zdobycia środków na utrzymanie Schroniska, czy też dla terapii pracą?" ${ }^{37}$.

Świadectwo pozostawione przez br. Jerzego wskazuje, że nie ma metody towarzyszenia duchowego, gdy brakuje terapii pracą, przy czym, w duchu wcześniej wspomnianej równości, ważne jest osobiste zaangażowanie terapeuty w pracę, a nie pozostawanie jedynie tym, kto kieruje do pracy. Wspólna praca rodzi braterstwo i tworzy unikalne warunki do nawiązania więzi pozwalającej na przebicie twardej skorupy otaczającej osoby wyprowadzane z bezdomności. W wywiadzie z października 2010 roku br. Jerzy powiedział: „Postawa opiekuna jest bardzo ważna, aby wdrażać podopiecznych do różnych prac. Ja na Lotniczej często sam zabierałem się do jakiejś dorywczej pracy, np. zbierania porozkładanych na trawie materaców, kiedy zaczynał padać deszcz. Wtedy wszyscy robili to ze mną, a przedtem nikt nie chciał się ruszyć" ${ }^{38}$.

Br. Jerzy zwracał uwagę na „niebezpieczeństwo dla wszystkich pracowników, żeby nie zaczęli uważać, że schronisko i podopieczni są tylko po to, aby mieć etaty i stanowisko - zamiast żeby uważać, że są oni po to, aby służyć podopiecznym, ocalać ich zdrowie i życie, przywracać im godność osoby ludzkiej”39. Pisał: „TPBA troszczy się o to, aby opiekunowie i kierownicy Schronisk nie traktowali swojej pracy tylko jako posiadanie etatu i zarobku, ale aby rozumieli ją

\footnotetext{
35 J. Marszałkowicz, Problemy działaczy..., dz. cyt.

36 J. Marszałkowicz, Rachunek sumienia: czy do wypetnienia..., dz. cyt.

37 J. Marszałkowicz, Rachunek sumienia prowadzących..., dz. cyt., nr 23.

38 R. Oktaba, Nieopublikowany wywiad..., dz. cyt.

39 J. Marszałkowicz, Problemy działaczy..., dz. cyt.
} 
jako ideową pracę dla swoich nieszczęśliwych braci i sióstr" ${ }^{30}$. A w wywiadzie z października 2010 roku br. Jerzy powiedział: „W schroniskach powinni pracować ludzie, którzy czują się w jakiś sposób powołani do pracy z podopiecznymi, a nie traktują ich jak przedmioty. Ważniejszą rzeczą niż dyplomy opiekuna jest jego właściwe podejście do człowieka jako człowieka, choćby był brudny, zasikany i zawszony"41. Dla br. Jerzego praca ma być wykonywana rzetelnie i starannie, na wzór tego, jak pracują albertyni. Jak mówił: „Motywem naszej pracy nie powinna być chęć zarobku"42.

Podsumowując, jeszcze raz przypomnę proponowaną przez mnie definicję towarzyszenia duchowego jako metody pracy socjalnej, gdzie przemawia się mniej słowami, a bardziej obecnością i własnym przykładem, z prowadzeniem walki duchowej mającej na celu uzyskanie wolności, przy zachowaniu równości między obiema stronami pomocy, z umiejętnością wykorzystywania porażek i deficytów, pokorą, odwagą, wytrwałością, poczuciem humoru, a także z wykorzystaniem starannej i rzetelnej pracy. Jestem przekonany, że wiele osób co dzień wykonuje pracę socjalną, stosując taką właśnie metodę.

\section{Bibliografia}

Crisp B., Spirituality and Social Work, Farnham 2010.

Marszałkowicz J., Mój Pamiętnik, Wrocław 2011.

Marszałkowicz J., Oświadczenie Wspólnoty Albertyńskiej co do tematu co to znaczy wykonywać pracę $w$ duchu św. Brata Alberta $\mathrm{z}$ dnia 28.VI.2006, maszynopis w posiadaniu TPBA.

Marszałkowicz J., Rachunek sumienia prowadzących schroniska, noclegownie i inne placówki TPBA, maszynopis w posiadaniu TPBA.

Marszałkowicz J., referat na otwarcie Zebrania Zarządu TPBA Dębicy w dniu 20.02.2009, maszynopis w posiadaniu TPBA.

Marszałkowicz J., Słowo wstępne na zebranie Zarządu Głównego TPBA, 20-21.11.2009 we Wrocławiu, maszynopis w posiadaniu TPBA.

Wywiad z Jerzym Marszałkowiczem w Radiu Maryja, 15 grudnia 2010 r.

Oktaba R., Nieopublikowany wywiad z Jerzym Marszałkowiczem przeprowadzony w październiku 2010, maszynopis w posiadaniu TPBA.

Rymsza M., Brat Albert jako prekursor pracy środowiskowej z bezdomnymi na ziemiach polskich, „Głos Brata Alberta” 2014, nr 1 (76), s. 28.

40 J. Marszałkowicz, Słowo wstępne na zebranie Zarządu Głównego TPBA, 20-21.11.2009 we Wrocławiu.

${ }^{41} \quad$ R. Oktaba, Nieopublikowany wywiad..., dz. cyt.

42 R. Oktaba, Nieopublikowany wywiad..., dz. cyt. 
Rymsza M., Od akcji dobroczynnej do pracy środowiskowej - działalność Brata Alberta $w$ środowisku ludzi bezdomnych $w$ Krakowie i innych miastach polskiej Galicji na przełomie XIX i XX wieku, w: Praca środowiskowa w Polsce - tradycja i teraźniejszość, red. M. Rymsza, Warszawa 2014.

Sieńczyk M., Aniszczyk B. (red.), Idea św. Brata Alberta we wspótczesnej pomocy osobom bezdomnym, Wrocław 2011.

Śledzianowski J., Towarzystwo Pomocy im. św. Brata Alberta a bezdomność, Wrocław 1995.

Stenka R. (red.), Raport z fazy diagnozy. Kondycja i dobre praktyki pomocy ludziom bezdomnym w sześciu obszarach: streetworking, praca socjalna, mieszkalnictwo i pomoc doraźna, partnerstwa lokalne, zdrowie, zatrudnienie i edukacja, Gdańsk 2011.

Wiktorska-Święcka A. (red.), Wyprowadzić na prosta. Innowacyjne metody aktywizacji społecznej i zawodowej na przykładzie wdrażania modelu lokalnej sieci wsparcia osób bezdomnych i zagrożonych bezdomnościa, Wrocław 2008.

Winowska M., Znieważane oblicze. Opowieść o św. Bracie Albercie, Kraków 2001.

Wojtyła K., Brat naszego Boga, Wrocław 2003.

Marszałkowicz J., Bezdomni w nowej rzeczywistości, referat z czerwca 2013,

https://docs.google.com/file/d/0B85s1tT6IvMQSmZlT0RLSzZ4bGs/edit (15.12.2016).

Marszałkowicz J., Czym jest Wspólnota Albertyńska działajaca w ramach TPBA? 17.05.2008, https://docs.google.com/file/d/0B85s1tT6IvMQZV9QMlJ6UDlnekk/edit (15.12.2016).

Marszałkowicz J., Problemy działaczy, opiekunów i pracowników oraz podopiecznych Schronisk św. Brata Alberta i innych placówek TPBA, 13.05.2006, https://docs.google.com/document/d/1gDwFBV2yIAhj6YQb7fxjVg8Rsb1QeF0sr0hfY9AKpk/edit (15.12.2016).

Marszałkowicz J., Rachunek sumienia: czy do wypetnienia testamentu Brata Alberta wystarczy szyld z jego imieniem? „Tygodnik Powszechny” 2002, nr 25 (2763), http://www.tygodnik. com.pl/numer/276325/marszalkowicz.html (15.12.2016).

Marszałkowicz J., Święty Brat Albert patrzał na bezdomnych oczyma wiary,

https://docs.google.com/file/d/0B85s1tT6IvMQMkE2dm00cERQaXc/edit (15.12.2016). 